Technologies. Vol. 5. No. 9 (101). 2019. pp. 16-27. DOI: https://doi.org/10.15587/1729-4061.2019.180197.

2. Shyshatskyi A., Tiurnikov M., Suhak S., Bondar O., Melnyk A., Bokhno, T., \& Lyashenko, А.. Методика оцінки ефективності системи зв'язку оперативного угруповання військ. Сучасні інформаційні системи. 2020. Том 4, № 1, с. 107-112. https://doi.org/10.20998/25229052.2020.1.16.

3. Демидов Б. А., Гриб Д. А., Хмелевская О. А. Концептуальные аспекты информатизации и автоматизации управления в вооруженных силах государства. Збірник наукових праць Харківського національного університету Повітряних Сил. 2017. № 5(54). С. 38-43.

4. Гриб Д. А., Демідов Б. О., Борисенко М. В., Кузнєцова М. Ю. Інформатизація управління структурною динамікою складних багато структурних систем військового призначення при динамічній зміні обстановки в районі ведення бойових дій. Збірник наукових праць Харківського національного університету Повітряних Сил. 2019. № 2(60). C. 7-15. https://doi.org/10.30748/zhups.2019.60.01.

5. Демідов Б. О., Кучеренко Ю. Ф., Матющенко О. Г. Основні напрямки застосування технологій, що містять елементи та методи штучного інтелекту, в оборонній сфері. Наука і техніка Повітряних Сил Збройних Сил України. 2018. № 4(33). С. 7-15. https://doi.org/10.30748/ nitps.2018.33.01.

DOI https://doi.org/10.30525/978-9934-26-172-5-3

\title{
ANALYSIS OF THE CURRENT ATTITUDE TO THE AUTOMATION OF THE FLIGHT PLANNING SYSTEM
}

\author{
Kolesnyk A. V. \\ Candidate of Technical Sciences, \\ Senior Lecturer at the Department of Information Technologies \\ Flight Academy of the National Aviation University \\ Kropyvnytskyi, Ukraine
}

In the flight planning process, the air traffic controller uses specialized software for planning the flight, monitoring the flight process and informing the crew of any circumstances that may affect flight safety.

The effectiveness of the current flight planning system depends on how close the developed flight route is to the optimal option in terms of achieving 12 
flight objectives, use of crew time and other resources, ensuring reliability [1, c. 214].

Moreover, the flight route must be calculated in such a way that any stage in the event of an adverse situation was provided the opportunity to continue the flight to achieve the goal set at this stage. In this regard, much attention is paid to the development and practical implementation of flight planning systems.

In modern man-machine complexes of flight planning there is a contradiction between the complexity of planning systems, the amount of information processed, the variety of decisions, finally, the required depth of plans, on the one hand, and poor study of flight planning, insufficient elaboration of general theory of flight planning, as well as the primitiveness of traditional "manual" planning technology, on the other hand.

This discrepancy leads to a mismatch between the required and actual levels of planning work, which in turn leads to the construction of insufficiently flexible and not fully balanced plans, deteriorating quality of flight planning in general.

The means of eliminating this contradiction is the automation of flight planning, aimed at $[2$, c. 21$]$ :

- improving the quality of planning by increasing the amount of information taken into account and the number of analyzed options for the plan;

- deeper elaboration and optimization of created plans;

- increase the flexibility and efficiency of planning through the use of preselected elements of planning, their careful verification of compatibility, availability of resources, compliance with various restrictions;

- more detailed elaboration of the composition of flight operations and connections between them at the initial stages of planning.

When creating automated information systems, the design of the database structure plays an important role [3, c. 16]. It is believed that such a structure should reflect not the algorithm of the created programs, but the real information processes occurring in the subject area, which is automated, for example, in the organization.

Designing a database, determining its rational structure is a very important step, which significantly affects the efficiency of the information system. This system is designed to automate flight plan processes related to obtaining, storing and processing information about future flights. The system accumulates all the data contained in the flight plan, ensures their integrity, safety, protection and reliability.

The creation of this tool allows you to automate the process of filling out the Flight Plan form, which provides the minimum flight time, the best 
possible route, combined with choosing the best alternate aerodrome for this route according to the flight characteristics of the aircraft.

Also, the automation of the Flight Plan, increases the accuracy of operation and quality of flight planning by significantly increasing the amount of information that is taken into account and the number of analyzed options for the flight plan.

This, in turn, allows for more in-depth elaboration and optimization of plans in general, increases the flexibility and efficiency of planning through the use of pre-selected planning elements (flight operations), their full and thorough verification of compatibility, resource availability, compliance with various constraints.

\title{
References:
}

1. Корнеев В.В., Гареев А.Ф., Васютин С.В., Райх В.В. Базы данных. Интеллектуальная обработка информации. Нолидж. 2000. С. 352.

2. Суркова К.В., Филоненко И.В. Разработка электронного средства обучения «Заявка на выполнение полетов». ГЛАУ. 2010. С. 27.

3. Неделько В.Н. Методы и средства компьютерных информационных технологий. М. 2005. С. 23.

DOI https://doi.org/10.30525/978-9934-26-172-5-4

\section{МЕТОДИКА ОЦІНЮВАННЯ ІНФОРМАЦІЙНО- АНАЛІТИЧНОГО ЗАБЕЗПЕЧЕННЯ СТРАТЕГІЧНОГО МЕНЕДЖМЕНТУ 3 ВИКОРИСТАННЯМ НЕЧІТКОЇ ЛОГІКИ}

\author{
Коробченко С. О. \\ кандидат технічних наук, \\ провідний науковий співробітник \\ Центральний науково-дослідний інститут озброєння \\ та військової техніки Збройних Сил Украӥни \\ м. Київ, Україна
}

У процесі стратегічного менеджменту центральне місце займають питання розробки і прийняття управлінських рішень, які в сучасних умовах неможливі без ефективної інформаційно-аналітичної підтримки. При цьому під стратегічним менеджментом прийнято розуміти цілеспрямовану діяльність відповідних посадових осіб для підтримки 